\title{
SOSIALISASI JENIS-JENIS TES BAHASA INGGRIS PADA GURU DI SDN DEPOK 4, PANCORAN MAS DEPOK
}

\author{
Laila Desnaranti, Febby Pratama Putra \\ Dosen Program Studi Pendidikan Ekonomi Universitas Indraprasta PGRI, Indonesia \\ lailaranti@gmail.com
}

\begin{abstract}
In this globalization era, teachers are required to achieve excellently in regional, national even in international forum. In order to perfomed excellently in international forum, the teachers must know how well their English are. To learn about their English competence, the teachers should follow the English test. However there are varied of English test which are held. The purpose of this community service program is to give explanation to the teacher about English test which can be selected appropriate with their needs. The result of the program is the increased of the teachers' knowledge about English test therefore they are able to determine which English test is in accordance with their need.
\end{abstract}

Keywords: Teacher, English tests

\begin{abstract}
Abstrak
Di era globalisasi ini guru dituntut agar dapat berprestasi baik di forum regional, nasional maupun di internasional. Agar dapat berprestasi dengan baik di forum internasional maka para guru harus mengetahui sampai sejauh mana kemampuan bahasa Inggris mereka. Untuk mengetahui sejauh mana kemampuan bahasa Inggris para guru, mereka dapat mengikuti tes bahasa Inggris. Tetapi banyak sekali jenis tes bahasa Inggris yang diselenggarakan. Tujuan dari kegiatan pengabdian masyarakat ini adalah untuk memberikan sosialisasi kepada para guru mengenai tes bahasa Inggris yang dapat diambil sehingga dapat sesuai dengan kebutuhan mereka. Hasil yang didapatkan dari kegiatan pengabdian masyarakat ini adalah meningkatnya pemahaman para guru mengenai tes bahasa Inggris sehingga nantinya mereka bisa menentukan tes mana yang sesuai dengan kebutuhan mereka.
\end{abstract}

Kata Kunci: Guru, Tes Bahasa Inggris

Submitted: 2020-09-07

Revised: 2020-10-02

Accepted: $2020-10-03$

\section{Pendahuluan}

Guru merupakan salah satu komponen penting dalam pendidikan. Tanpa adanya guru maka pendidikan tidak akan dapat berjalan dengan baik. Agar guru dapat mengikuti perkembangan yang semakin cepat maka para guru juga harus mulai mengembangkan kemampuan yang mereka punya. Tujuan dari pengembangan kemampuan guru adalah agar profesi guru dapat menjadi profesi yang bermartabat sesuai dengan hal ingin dicapai dalam Undang - Undang Nomor 14 tahun 2005 tentang guru dan dosen. Dengan menguasai ilmu pengetahuan dan teknologi diharapkan guru terampil dalam membangkitkan minat peserta didik kepada ilmu pengetahuan dan teknologi melalui layanan pendidikan yang bermutu (Pedoman Kegiatan Pengembangan Keprofesian Berkelanjutan Bagi Guru Pembelajar, 2016).

Saudagar (dalam Sutrisno dan Aisyah, 2012:37) mengatakan bahwa guru sebagai profesi secara umum dipersyaratkan empat kompetensi, yaitu: mendidik, mengajar, 
melatih, dan membimbing sehingga guru dituntut untuk terus menerus meningkatkan kemampuan serta keterampilannya. Krishnaveni dan Anita (dalam Sutrisno dan Aisyah, 2012:37) juga menjelaskan bahwa aspek keterampilan guru sebagai salah satu karakteristik guru profesional. Keterampilan meliputi aspek perihal kemampuan pengetahuan, kecakapan mengajar, dan perbaikan pengetahuan. Menurut Krishnaveni ketiga karakteristik tersebut berkontribusi dalam meningkatkan kompetensi profesional seseorang terutama dalam mengajar. Kompetensi menurut Gonczi (dalam Nurhasanah, 2017:51) bersifat kompleks dan merupkan kesatuan yang utuh yang menggambarkan potensi, pengetahuan, keterampilan, sikap dan nilai yang dimiliki seseorang terkait dengan profesi tertentu dan berkenaan dengan bagian-bagian yang dapat diaktualisasikan dalam bentuk tindakan atau kinerja untuk menjalankan profesi tersebut.

Salah satu ilmu pengetahuan yang harus dikuasai oleh guru pada masa sekarang ini untuk mengembangkan diri adalah keterampilan dalam berbahasa. Khususnya keterampilan dalam menggunakan bahasa Inggris mengingat bahwa situasi sekarang ini dimana kita sudah memasuki era globalisasi. Hanya dengan menekan satu tombol maka kita dapat terhubung dan berkomunikasi dengan seseorang dari negara lain. Maka agar guru menjadi individu yang profesional tidak ada salahnya apabila guru juga menguasai bahasa asing khususnya bahasa inggris yang merupakan bahasa yang paling banyak dipakai di seluruh dunia.

Hal ini sejalan dengan Undang - Undang Republik Indonesia No. 20 Tahun 2003 tentang Sistem Pendidikan Nasional, jabatan guru sebagai pendidik merupakan jabatan professional. Untuk itu profesionalisme guru dituntut agar terus berkembang sesuai dengan perkembangan jaman, ilmu pengetahuan dan teknologi, serta kebutuhan masyarakat termasuk kebutuhan terhadap sumber daya manusia yang berkualitas dan memiliki kapabilitas untuk mampu bersaing baik di forum regional, nasional maupun internasional (Supriyadi: 2009). Agar para guru dapat bersaing di forum internasional maka kemampuan berbahasa Inggris sangatlah diperlukan. Untuk itu para guru juga harus dibekali pengetahuan mengenai tes bahasa Inggris apa saja yang dapat mereka ambil supaya mereka dapat mengetahui sampai sejauh mana kemampuan bahasa Inggris mereka.

Banyak jenis tes bahasa Inggris yang dapat diambil guna mengetahui kompetensi penguasaan bahasa Inggris seseorang. Beberapa jenis tes bahasa Inggris yang umum dipergunakan adalah TOEFL (Test Of English as a Foreign Language), IELTS (International English Language Testing System) dan TOEIC (Test Of English for International Communication). Sebagai pengguna tes ada baiknya kita mengetahui apa kegunaan dari masing - masing tes agar kita dapat memilih tes yang sesuai dengan kebutuhan. Memilih tes yang sesuai dengan kebutuhan dapat membantu dalam mencapai tujuan yang ingin dicapai oleh peserta tes.

Kuspiah, Rohmah dan Marwati (2016:103) menyatakan bahwa TOEFL (Test Of English as a Foreign Language) adalah salah satu model pengujian bahasa Inggris yang digunakan untuk mengukur tingkat kecakapan atau profisiensi mereka yang tidak menggunakan bahasa Inggris sebagai bahasa ibu atau disebut nonnative speaker. TOEFL adalah sebuah tes terstandarisasi yang biasanya digunakan untuk mengetahui kemampuan bahasa Inggris seseorang sebagai penutur bahasa asing (Brown dalam Sucahyo, 2016:103). TOEFL sendiri paling banyak digunakan di Indonesia. TOEFL 
merupakan salah satu aspek dalam pelatihan bahasa Inggris yang menekankan pada peningkatan penguasaan skil dasar seperti structure, reading, dan listening (Kartikawati, Fitriningtyas, dan Frisdiana, 2014: 11). Pembelajaran bahasa Inggris yang tepat mencakup keterampilan berbicara dan menyimak, membaca dan menulis, yang memiliki domain kompetensi, kreativitas, pemahaman budaya, dan pemikiran kritis. Keempat aspek tersebut membantu pembelajar untuk memperdalam dan memperluas pengetahuan, pemahaman, serta perkembangan dalam bahasa Inggris (Clarke, Dickinson, dan Westbrook, 2010:25). Hasil tes TOEFL dapat dipergunakan untuk melamar pekerjaan serta melanjutkan pendidikan baik di dalam maupun diluar negeri.

Menurut Saifudin, dkk (2007:20) TOEFL terdiri dari dua jenis, yaitu Computer-Based Testing (CBT) and Paper-Based Testing (PBT). Computer-Based Testing (CBT) adalah ujian TOEFL yang menggunakan komputer. Skala penilaian model ini berkisar antara 40 300. Sedangkan Paper-Based Testing (PBT) adalah ujian TOEFL yang menggunakan kertas. Skor untuk penilaian model ini berkisar antara 217 - 677. Saifudin, dkk (2007:21) juga menjelaskan bahwa ada empat bagian yang diujikan dalam TOEFL, yaitu Listening Comprehension, Structure and Written Expression, Reading Comprehension serta Test of English Written.

IELTS (International English Language Testing System) merupakan tes yang memakai tulisan dan aksen British English dimana terdapat idiom, ejaan dan logat yang berbeda dengan American English yang digunakan oleh tes TOEFL. Tes ini sangat dikenal karena tingkat kesulitan yang cukup tinggi dan membutuhkan strategi yang tepat untuk menjawab dan mendapatkan skor yang cukup. Ada dua jenis tes IELTS yaitu General Training dengan tujuan untuk bekerja dan Academic Training dengan tujuan untuk belajar. IELTS memiliki empat bagian yakni listening, reading, writing dan speaking.

Test Of English for International Communication atau TOIEC biasanya dipergunakan untuk keperluan pekerjaan. Tes ini dilaksanakan untuk mengetahui kemampuan seseorang untuk berkomunikasi secara baik dilingkungan pekerjaan dan secara umum. Tidak hanya perusahaan luar negeri saja yang menggunakan tes ini, perusahaan dalam negeri juga menggunakannya untuk mengetahui kemampuan bahasa Inggris karyawannya. TOIEC dibagi dalam 2 bagian yakni reading dan listening. Apabila peserta tes mendapatkan nilai minimal 600 pada ujian reading dan listening maka baru akan dianjurkan untuk mengikuti tes bagian writing dan speaking.

Berdasarkan pernyataan diatas didapatkan bahwa setiap tes bahasa Inggris memiliki tujuannya masing - masing oleh karena itu ada baiknya bagi para peserta tes untuk mengetahui hal tersebut. Sehingga mereka dapat memilih tes yang sesuai dengan kebutuhan mereka dan dapat memaksimalkan hasil yang mereka dapatkan.

Di era globalisasi ini guru juga dituntut agar dapat berprestasi baik di forum regional, nasional maupun di internasional. Agar dapat berprestasi dengan baik di forum internasional maka para guru harus mengetahui sampai sejauh mana kemampuan bahasa Inggris mereka. Menurut Rakhmadi dan Nugroho (2009:40) Bahasa Inggris merupakan bahasa internasional yang paling penting, dan juga sebuah alat komunikasi di era globalisasi modern dan komunitas yang global. Untuk mengetahui sejauh mana kemampuan bahasa Inggris para guru, mereka dapat mengikuti tes bahasa Inggris. Tetapi banyak sekali tes bahasa Inggris yang diselenggarakan, agar dapat memilih tes 
bahasa Inggris yang tepat sehingga hasil yang diperoleh dapat maksimal maka para guru harus diperkenalkan lebih dulu mengenai tes bahasa Inggris tersebut.

\section{Metode}

Kegiatan pengabdian kepada masyarakat ini dilakukan dalam 2 tahap, yakni sosialisasi mengenai jenis - jenis tes bahasa Inggris yang ada beserta fungsi dari tes-tes tersebut dan simulasi salah satu tes yaitu TOEFL. Tes TOEFL dipilih karena banyak dipakai di Indonesia untuk menentukan kemahiran bahasa Inggris seseorang. Tahap simulasi dibagi menjadi 2 bagian yakni simulasi untuk listening dan reading.

Sasaran dari kegiatan pengabdian masyarakat ini adalah para guru yang mengajar di SDN Depok 4 dan kegiatan ini berlangsung di SDN Depok 4. Dalam kegiatan ini disampaikan mengenai jenis-jenis tes bahasa Inggris yang ada dan juga fungsinya masing-masing. Setelah kegiatan sosialisasi selesai maka kegiatan selanjutnya adalah mengadakan simulasi tes Toefl yang dibagi menjadi 2 kegiatan. Simulasi listening dan juga pemberian tips and trick untuk tes TOEFL bagian listening yang diadakan esok harinya. Besoknya lagi tim abdimas mengadakan simulasi untuk reading dan ditambah grammar juga tips and trick untuk bagian tersebut. Jadi kegiatan ini dilaksanakan dalam 3 kali pertemuan. Evaluasi akan dilakukan untuk melihat peningkatan pemahaman para peserta mengenai jenis-jenis tes bahasa Inggris beserta fungsinya

\section{Hasil dan Pembahasan}

Tujuan dari kegiatan pengabdian kepada masayarakat ini adalah untuk memberikan sosialisasi kepada guru mengenai jenis - jenis tes bahasa Inggris yang ada. Diharapkan setelah kegiatan pengabdian kepada masayarakat ini selesai, para guru dapat memahami mengenai tes - tes bahasa Inggris yang ada dan mereka dapat memilih tes bahasa Inggris yang sesuai dengan kebutuhan sehingga mereka mendapatkan hasil yang memuaskan.

Sebelum melaksanakan kegiatan pengabdian kepada masyarakat, tim datang ke sekolah dan bertemu dengan kepala sekolah. Dalam pertemuan dengan kepala sekolah tim abdimas menjelaskan permasalahan yang tim dapatkan dari observasi dan wawancara dengan para guru. Di pertemuan tersebut jugalah tim abdimas berdidiskusi dengan kepala sekolah mengenai solusi permasalahan yang didapatkan. Solusi yang didapatkan setelah berdiskusi dengan kepala sekolah adalah mengadakan sosialisasi kepada para guru mengenai berbagai macam tes bahasa Inggris yang ada di Indonesia dan mengadakan simulasi tes TOEFL serta memberikan tips dan trick bagaimana mengerjakan tes sehingga dapat menghasilkan nilai yang memuaskan. Tes TOEFL dipilih karena di Indonesia banyak sekali yang memakai TOEFL sebagai tes pengukuran bahasa Inggris. Agar para guru dapat terbiasa maka tim abdimas beserta kepala sekolah menentukan bahwa simulasi tes yang akan dilakukan adalah tes TOEFL.

Pelaksanaan kegiatan pengabdian kepada masyarakat ini dilaksanakan dalam 2 tahap. Kedua tahap tersebut terdiri dari sosialisasi dan simulasi. Dalam tahap simulasi selain para guru melakukan simulasi tes, tim abdimas juga akan memberikan beberapa tips dan trick untuk melakukan tes bahasa Inggris. Setiap pertemuan berlangsung selama 
90 menit. Kegiatan pengabdian kepada masyarakat ini diadakan di SDN Depok 4 dengan menggunakan ruang guru.

Tahap pertama dari kegiatan pengabdian kepada masyarakat ini diadakan pada tanggal hari Senin, 28 Oktober 2019. Kegiatan pengabdian kepada masyarakat ini diikuti oleh 14 guru. Kegiatan diawali dengan perkenalan dari anggota tim abdimas, konsep serta rundown kegiatan. Kegiatan yang dilakukan pada tahap pertama ini adalah sosialisasi mengenai berbagai jenis tes bahasa Inggris yang ada. Tim abdimas memutarkan video mengenai jenis - jenis tes bahasa Inggris. Setelah itu tim menjelaskan satu persatu jenis - jenis tes yang sering dipergunakan guna mengukur kemampuan bahasa Inggris seperti TOEFL, IELTS, dan juga TOIEC.

Respon dari para guru sangat baik, terlihat dari banyaknya pertanyaan yang diajukan. Seperti berapa lama nilai dari tes TOEFL berlaku, biaya yang harus dibayarkan jika akan mengikuti salah satu tes, berapa nilai terendah dan tertinggi dari tiap tes, tes manakah yang dapat dipakai untuk melanjutkan pendidikan mereka, dan masih banyak yang lainnya. Acara sosialisasi ini dimulai dari pukul 13.00 sampai dengan pukul 14.30 dan kegiatan sosialiasi ini berjalan dengan lancar.

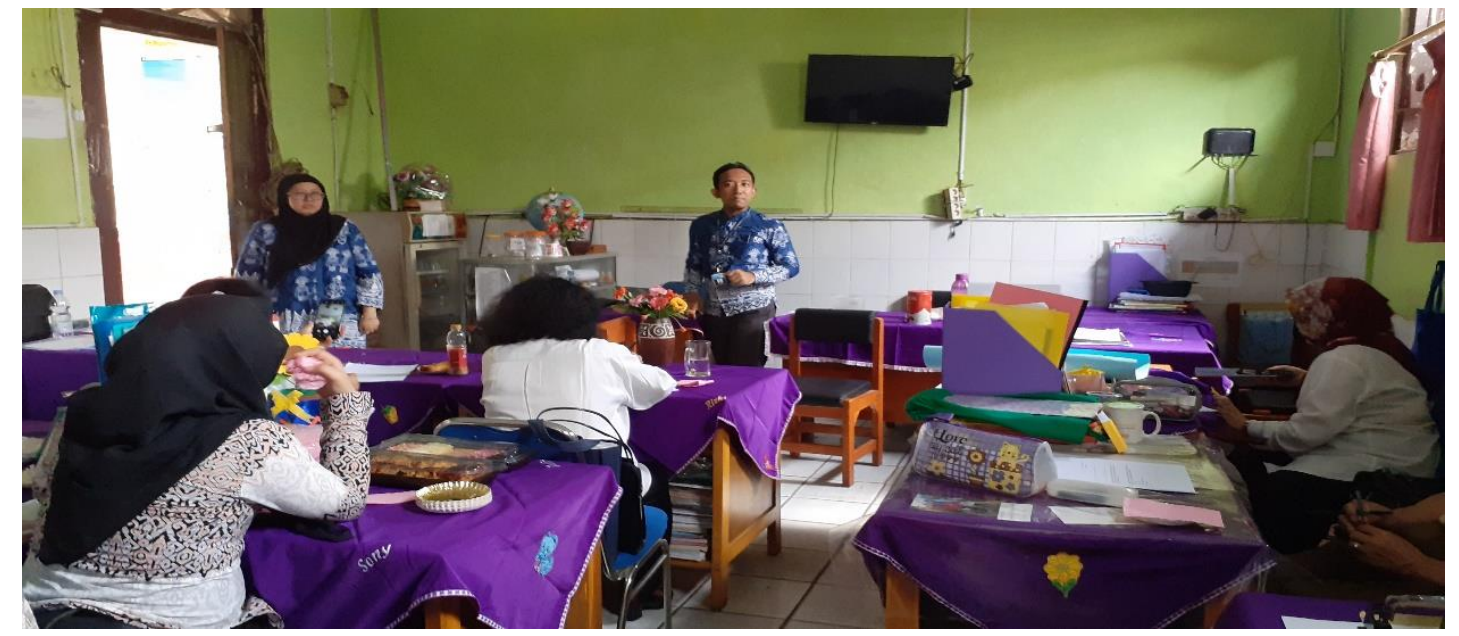

Gambar 1. Sosialisasi Jenis-Jenis Tes Bahasa Inggris

Tahap kedua dari kegiatan pengabdian kepada masyarakat ini adalah dengan mengadakan simulasi tes TOEFL menggunakan power point. Kegiatan dilaksanakan pada tanggan 30 Oktober 2019. Kegiatan tahap dua ini dilakukan mulai dari pukul 13.00 sampai dengan pukul 14.30. Kegiatan pengabdian kepada masyarakat ini diikuti oleh 14 guru. Tim abdimas memberikan simulasi berupa pertanyaan - pertanyaan listening yang berisi percakapan pendek dengan menggunakan power point. Setelah itu tim meminta para guru untuk mencoba menjawab pertanyaan. Kemudian tim abdimas membahas jawaban untuk pertanyaan tersebut serta memberikan saran bagaimana menjawab pertanyaan tersebut dengan cepat dan tepat. Para guru terlihat sangat tertarik dengan materi listening dimana mereka berusaha dengan semampu mereka untuk mendengarkan dan mencoba menjawab pertanyaan dengan benar.

Esok harinya pada tanggal 31 Oktober 2019, tim abdimas melanjutkan simulasi untuk tes reading dan grammar TOEFL. Kegiatan ini dilaksanakan pada pukul 13.00 
sampai dengan 14.30 dan dihadiri oleh 14 guru. Tes simulasi yang dilakukan menggunakan power point. Tim abdimas juga membagikan contoh soal TOEFL kepada para guru. Tim abdimas memberikan waktu para guru untuk membaca dan memahami teks pendek (short teks) sekitar 5 menit dan menjawab pertanyaan yang menyertai teks tersebut. Para guru diperbolehkan untuk menggunakan smartphone untuk penggunaan kamus atau google translate. Setelahnya tim abdimas membahas soal tersebut dan menjelaskan mengenai alternatif jawaban yang dibuat agar para peserta tes bingung. Tim abdimas memberikan tips dan trick untuk mengatasi hal tersebut.

Setelah tes reading tim abdimas melanjutkan membahas soal - soal grammar TOEFL. Para guru diberikan kalimat yang tidak lengkap dan diminta untuk memilih jawaban yang menurut mereka tepat untuk melengkapi kalimat tersebut sehingga menjadi kalimat yang benar. Para guru diberi waktu 20 menit untuk mencoba menjawab pertanyaan dengan tepat. Sesudahnya tim abdimas membahas soal grammar tersebut bersama dengan para guru.

Para guru sangat antusias dengan kegiatan terakhir ini. Banyak guru yang memberikan pertanyaan mengenai tata bahasa (grammar). Para guru juga merasa pengetahuan mereka mengenai tes bahasa Inggris menjadi bertambah. Mereka juga merasa sangat terbantu dengan tips dan trick yang diberikan oleh tim abdimas dalam memecahkan soal - soal TOEFL yang sebelumnya menurut mereka sulit.

Secara keseluruhan kegiatan pengabdian masyarakat untuk menambah pengetahuan para guru mengenai tes bahasa Inggris agar mereka dapat memilih tes bahasa Inggris sesuai dengan kebutuhan merka berjalan dengan lancar. Para guru sangat antusias dalam mengikuti kegiatan tersebut walaupun tidak semua guru dapat mengikuti kegiatan tersebut dikarenakan mereka harus mengajar. Para guru yang mengikuti kegiatan banyak memberikan pertanyaan mengenai tes yang diperkenalkan.

Begitu juga saat diadakan simulasi tes, banyak dari para guru yang mengajukan pertanyaan mengenai cara agar dapat menjawab pertanyaan yang ada dengan tepat. Saat tim abdimas memberikan tips dan trick, para guru sangat bersemangat. Mereka banyak bertanya mengenai hal tersebut. Setelah diadakannya kegiatan pengabdian kepada masyarakat ini, ada beberapa guru yang ingin melanjutkan pendidikan mereka ke jenjang S2. Sebelumnya mereka sempat merasa ragu karena mereka merasa tidak dapat melewati tes bahasa Inggris yang biasanya diadakan sebagai salah satu persyaratan agar dapat diterima di perguruan tinggi. Tetapi setelah diadakannya kegiatan ini mereka mendapatkan rasa percaya diri mereka untuk melanjutkan pendidikan mereka.

Kegiatan pengabdian kepada masyarakat ini telah berhasil terlaksana dengan baik. Selama pelaksanaan kegiatan pengabdian kepada masyarakat yang berlokasi di SDN Depok tidak terdapat kendala yang berarti dimana berarti kegiatan ini mendapat dukungan penuh dari mitra SDN Depok 4, yang terdiri dari kepala sekolah dan para guru.

Kegiatan abdimas berupa sosialisasi untuk meningkatkan pengetahuan dan pemahaman para guru terhadap tes bahasa Inggris bertujuan agar para guru dapat memilih tes bahasa Inggris mana yang mereka perlukan sesuai dengan kebutuhan mereka. Kebutuhan tersebut apakah untuk melanjutkan pendidikan, meningkatkan kompetensi dan lainnya. Selain itu para guru juga diberikan simulasi tes bahasa Inggris. Tes yang dipilih adalah tes TOEFL, karena banyak negara yang menggunakan tes ini sebagai tes standar. Selain simulasi, para guru juga diberikan tips dan trick dalam 
menyelesaikan tes bahasa Inggris tersebut. Diharapkan dengan diberikan tips dan trick dapat membantu para guru mendapatkan hasil tes yang memuaskan. Setelah pelaksanaan kegiatan pengabdian kepada masyarakat terlihat para guru mulai memahami mengenai jenis - jenis tes bahasa Inggris yang ada dan mereka mulai bertanya bagaimana caranya untuk dapat mengikuti tes bahasa sehingga mereka dapat melanjutkan pendidikan mereka serta ikut berprestasi di kancah internasional.

\section{Kesimpulan}

Kegiatan pengabdian kepada masyarakat yang berupa sosialisasi kepada para guru mengenai jenis - jenis dari tes bahasa Inggris serta kegunaan dari tes tersebut telah terlaksana dengan baik. Selain kegiatan sosialisasi tim pengabdian kepada masyarakat juga memberikan tips dan trick kepada para guru agar mereka nantinya pada saat melaksanakan tes bahasa Inggris mereka dapat terbantu dengan tips dan trick yang diajarkan. Kegiatan ini terlaksana dengan baik dapat terlihat dari penggunaan tips and trick yang diajarkan saat para guru mengikuti simulasi dari tes TOEFL yang dilaksanakan sebagai bagian dari kegiatan pengabdian kepada masyarakat ini. Hasil yang dicapai dari kegiatan pengabdian kepada masyarakat di SDN Depok 4 adalah terdapat adanya peningkatan pengetahuan dan pemahaman dari para guru akan tes bahasa Inggris yang ada. Diharapkan dengan terlaksananya kegiatan pengabdian kepada masyarakat ini, para guru dapat terbantu dalam memutuskan untuk mengambil jenis tes bahasa Inggris yang sesuai dengan kebutuhan mereka.

Selain itu, tim pengabdian kepada masyarakat juga memberikan saran kepada para guru untuk lebih mempelajari lagi tips dan trick yang sudah diberikan untuk mengerjakan tes TOEFL dan akan lebih baik lagi jika mereka juga mencari tips dan trick lainnya yang belum diberikan agar mereka dapat mengerjakan tes TOEFL serta tes bahasa Inggris yang lainnya dengan baik. Selain itu para guru juga sebaiknya menambah perbendaharaan kosakata bahasa Inggris agar pada saat mengikuti tes bahasa Inggris tidak merasa kesulitan untuk menjawab pertanyaan. Hal ini dapat dilakukan dengan cara banyak membaca buku atau artikel berbahasa Inggris. Para guru juga dianjurkan untuk banyak berlatih mengerjakan tes bahasa Inggris yang sudah mereka pilih sebelum melaksanakannya. Menurut Ward (dalam Roza, 2019:2) persiapan ujian yang berhasil diperlukan untuk meningkatkan tes kemahiran bahasa pembelajar. Diharapkan dengan banyak berlatih dapat membantu mereka untuk mendapatkan hasil yang memuaskan.

\section{Daftar Pustaka}

Clarke, S., Dickinson, P., Westbrook. J. (2010). Becoming ang English Teacher. London: Sage Publishing.

Kartikawati, D, Fitriningtyas, A \& Frisdiana, W I. (2014). Peningkatan Kemampuan TOEFL Bagi Guru-Guru SMA di Kabupaten Tulungagung. J-ADIMAS (Jurnal Pengabdian kepada Masyarakat), 2(1), 10-13

Kementrian Pendidikan dan Kebudayaan. (2016). Pembinaan dan Pengembangan Profesi Guru Buku 4 Pedoman Kegiatan Pengembangan Keprofesian Berkelanjutan Bagi Guru Pembelajar. Jakarta. Direktorat Jendral Guru dan Tenaga Kependidikan 
Nurhasanah, S. (2017). Pelatihan Peningkatan Kompetensi Berbahasa Inggris Guru dalam Pembelajaran Bilingual di SDIT Bilingual Fithrah Insani Kabupaten Bandung Barat. Jurnal Empowerment Volume. 6(1), 50-57.

Rakhmadi, A \& Nugroho, L E. (2009). Implementasi dan Evaluasi English E-Learning Berbasis Web untuk TOEFL Preparation. Seminar Nasional Aplikasi Teknologi Informasi (SNATI 2009). Yogyakarta.

Roza, D. (2019). The Challenges and Strategies in Teaching TOEFL and IELTS Test Preparation. J-SHMIC: Journal of English for Academic. 6(2).

Saifudin, Irham, A, dkk. (2007). TOEFL: Pengantar Pembahasan, Strategi dan Pelatihanya. Jogjakarta. DIVA Press.

Sucahyo, S A. (2016). Peta Nilai TOEFL Mahasiswa Program Studi Pendidikan Bahasa Inggris Institut Agama Islam Negeri Samarinda. Jurnal Fenomena, 8(1), 101-109.

Supriyadi, E. (2009). Peran Perguruan Tinggi Dalam Menyiapkan Calon Guru Sekolah Bertaraf Internasional. UNY

Sutrisno, B \& Aisyah. (2012). Pengembangan Profesional Guru Rintisan SMA Bertaraf Internasional (RSMABI) di SMA Negeri 1 Temanggung. Varia Pendidikan, 24(1).

https://www.vistaeducation.com/news/v/all/perbedaan-test-toefl-toeic-ielts-gre-dan-gmat 